\title{
The Traumatic Mark in Invisible Man
}

\author{
Xinyao Du \\ School of Foreign Languages and Literature, Chongqing Normal University, China
}

\begin{abstract}
Invisible Man is the representative work of Ralph Ellison, a famous contemporary American black writer, which mainly describes the growing process of a black man. The aim of the thesis is to analyze the racial trauma that the protagonist experienced at school, in the factory and political group, the three kinds of symptoms after the trauma-hyperarousal, intrusion and constriction, and the result that the protagonist cannot recover from his trauma due to racial discrimination.
\end{abstract}

Index Terms - trauma, post-traumatic stress disorder, recovery of trauma

\section{INTRODUCTION}

Ralph Ellison (1914-1994), as a contemporary black American writer, spent seven years finishing his first novel Invisible Man which was recognized as the most important and influential novel. Thanks to this famous novel Invisible Man, he won American Medal of Freedom and was admitted to the American academy of sciences. In 1914, Ellison was born in Oklahoma City and his name was taken from the poet Ralph Waldo Emerson, because his father expected him to be a poet like Emerson. When he was a child, he loved music and received a scholarship to Tuskegee Institute for learning music. Due to something wrong with the scholarship, he had to move to New York where he started to engage in literary creation with the encouragement of the famous black poet Langston Hughes and the novelist Richard Wright. (Wang, 1993) In the early stage, he mainly wrote comment articles and published two collections of essays Shadow and Act and Going to the Territory which expounds his view on literature, music and the political life of black Americans. In 1952, the famous novel Invisible Man was published.

In Invisible Man, the author narrates that a young, nameless man seeks for individuality in the society full of racial discrimination and segregation and becomes mature in psychology. The content of this novel involves three parts: the life in South Negro University, the encounter in freedom paint factory of New York and the experience in Harlem as well. The author expresses complex and abstruse themes though a seemingly simple storyline so that it can be comprehended from different perspectives.

Some scholars examined this novel by adopting the approach of post-colonialism or by exploring the existential theme of protagonist's life experience and the symbolism of characters' identity. From their research achievements, it can be seen that theme of this novel, existential identity and the resources caused the young man's invisibility.

However, few scholars analyzed this novel from the perspective of trauma theory. Trauma Theory involves Post-traumatic Stress Disorder and Recovery and is widely apply to psychiatry. From this perspective, we can experience the injury the black young man got in the white-dominated society.

This thesis will probe the black young man's experience on the basis of trauma theory and the influence on the man's self-identification. It not only provides a new perspective for us to comprehend this novel but also fills with enlightenment for everyone's journey.

\section{TRAUMA THEORY}

\section{A. The Development of Trauma Theory}

The word "trauma" comes from Greek, and integrates with literature at the beginning of 1990. It is believed that the origin of trauma theory can be traced to America in 1980. At that time, Vietnam War veterans held a constant political movement and organized inflammatory groups against the war, which increases public understanding of the consequence of war and public support for veterans. They also entrusted a specialized institution to study the influence of wartime experience on combatant and proved that there was a direct relationship between Post-trauma Stress Disorder and war. Thus, PTSD was put into the diagnostic criteria in American medical and psychiatric profession.

Trauma theory rose at the end of $19^{\text {th }}$ century, and Freud was the first one to study trauma. He analyzed trauma in the aspect of sex, consciousness and desire at first. And then, Freud shifted his attention to the psychological trauma of the war, aiming to study the relationship between combat neurosis and moral personality of the patient so that he could help them recover from trauma. Freud's study of trauma laid a solid foundation for subsequent trauma studies. (Tao, 2011)

In the 1890 s, a large number of important scholars have sprung up to study trauma theory and their subjects also began to diverge. And of all the researchers, Cathy Caruth was the most remarkable who was first to put "Trauma theory". Relating to the American psychological association description of PTSD, he further examined characteristics of traumatic experience on the basis of Freud's study. In his study, traumatic events can be sudden and catastrophic, then appear repeatedly so that traumatic experience will make the subject feel hard to handle. What's more, the traumatic 
experience will exist in the mind of the person affected, to the extent that the heart of the person who was injured has been carrying the trauma of the experience can't face. (Caruth, 2016)

The factors led to traumatic experience are complex and extensive. It may come from flood, earthquake, fire disaster, war, or due to violence, ignorance and emotional abuse. In the $20^{\text {th }}$ century, a famous psychiatrist - Judith Herman who promotes the development of trauma theory mentioned in her work Trauma and Recovery that "Psychological trauma is an affliction of the powerless. At the moment of trauma, the victim is rendered helpless by overwhelming force. When the force is that of nature, we speak of disasters. When the force is that of human beings, we speak of atrocities." (Herman, 2015, p.33)

From what is mentioned above, it can be seen that trauma theory is important for the definition of trauma. And this thesis mainly studies protagonist's psychological trauma in Invisible Man in the help of Herman's work Trauma and Recovery.

\section{B. Post-Trauma Stress Disorder}

In Trauma and Recovery, Herman analyzes trauma theory from three aspects: the nature of traumatic event, post-trauma stress disorder and the trauma recovery. (Xu, 2018)

Trauma events undermine human's ability to adapt to daily life. The severity of trauma events cannot be measured by any single dimension. When one is in danger, the sense of threat puts one on alert. The one will feel angry, tired and painful, and then the sense of threat will cause intense fear and anger. Then these responses make threatened individuals armed to resist and escape. (Herman, 2015) Human's self-defense system will be broken by trauma when resistance and escape do not work, which is the key point PTSD focus on.

"The many symptoms of post-traumatic stress disorder fall into three main categories: hyperarousal, intrusion and constriction." (Herman, 2015, p.35) Hyperarousal means constant expectation of danger. Once one has trauma experience, he or she will be on high alert as if danger would happen at any time. Their bodies are ever alert to danger, and unexpected stimulus or specific stimulus related to their trauma experience will make them extremely panic. Intrusion means memories of traumatic moments linger in one's mind. Even the danger has passed for a long time, injured one will still experience the same trauma event in his or her mind repeatedly. Constriction means the numbing reaction after giving in. One who show this symptom feels utterly powerless and despaired as if his or her soul has separated from body. (Herman, 2015)

\section{Recovery of Psychological Trauma}

The recovery of trauma plays an important role in a person's traumatized life, which begins only when the survivor is aware of it. However, the recovery of psychological trauma is hard and arduous task. According to Herman, the process of recovery of trauma can be divided into three stages: the establishment of safety, remembrance and mourning, reconnect with others. The first step of recovery is to establish the survivors' sense of safety which is the premise for other treatment. The second step is that traumatized person begins to tell her trauma story at length. This task is to transform the patient's traumatic memory so that it can be a part of his life. The third step is to reconnect with others. (Herman, 2015) In this progress, the task for the survivor is to create the future because he was able to give his trust to someone trustworthy again. Reconnecting with others will contribute to developing a new relationship with others. If three tasks above are finished, it's time for traumatized person to rebirth.

\section{TRAUMA EXPERIENCE IN SEARCHING FOR INDIVIDUAL IDENTITY}

\section{A. As a College Student}

The invisible man was an honest man who tried to get recognition from others, therefore he tried to create himself according to the values instilled in him by his school education. In white club, he was taken to join the fight between black boys and forced to crawl over the electric blanket to grab the coin. His speech delivered in the club won the award scholarship for black college. The protagonist took the president of the college Dr. Bledsoe as an idol and was always deferential toward him. However, when he was assigned to take the white board Mr. Norton to the slum inadvertently, he made him see the dirty and messy of the black. In order to publish him, Dr. Bledsoe pretend to writing reference letters for him to find a job but actually make him never find a job. Having experiencing these traumas when he was a college student, invisible man showed the following symptom:

\section{Hyperarousal}

"After a traumatic experience, the human system of self-preservation seems to go onto permanent alert, as if the danger might return at any moment." (Herman, 2015, p.35) It is the first symptom of post-traumatic stress disorder-hyperarousal. It can be seen that the protagonist showed this symptom when he attended the white social gathering.

At white social gatherings, invisible man rushed up into the front of ballroom where stood a magnificent blonde. However, the protagonist felt a sense of fear, as the author described in this book: "I felt a lot of cold chill me" "I felt a wave of irrational guilt and fear. My teeth chattered, my skin turned to goose flesh, my knees knocked." (Ellison, 1995, p.24) In such case, even danger did not appear, he also felt a sense of cold and fear as if danger was coming. He could 
infer that the blonde would have bad experience and felt powerless. From her eyes, invisible man felt that the fear in her eyes was almost exactly the same as the fear he had felt and that he had found in some of his companions. Those who had experienced trauma event before will remind themselves of their own trauma experience at the sight of others' suffering. What's more, traumatic patients will feel guilt when they witness others' suffering or death in terms of Herman's view. (Herman, 2015) Thus, that is why invisible man felt guilt and fear when he saw the blonde.

\section{Intrusion}

According to Herman, "long after the danger is past, traumatized people relive the event as though it were continually recurring in the present." (Herman, 2015, p.37) It is the second symptom of traumatic stress disorder-intrusion, which can be found in his contact with Mr. Norton.

In the Golden Day, Mr. Norton lost consciousness again in the pushing and shoving of others. Invisible man was pushed into Mr. Norton's body and his face gave the protagonist a nameless dread. He was never so close to the white and was afraid of the "white ghost". In the protagonist's mind, they had to obey the white to get recognition and got accustomed to suffering from them. He never dared to be close to the white, so Mr. Norton's face reminded him of what he suffered and experienced in the past. Because of how scaring his memory about the white is, even the white's face will give him the same feeling as the past. At this time, he showed the symptom of intrusion.

\section{Constriction}

The third main symptom of PTSD is constriction. According to Herman: "When a person is completely powerless, and any form of resistance is futile, she may go into a state of surrender." (Herman, 2015, p.42) At that time, he will feel numb and helpless.

Invisible man came to New York to find a job with Dr. Bledsoe's reference letter. After several letters didn't help him get reply he expected, he started to feel scared with no reason. In his dream at that night, his grandfather appeared, which make him feel that he played a role in a conspiracy hatched by Dr. Bledsoe and Mr. Norton. Later, a recipient of the letter gave him the letter to read, knowing the truth at least. He felt despaired and sat on the bed laughing. Just like the author described: "I laughed and felt numb and weak, knowing that soon the pain would come and no matter what happened to me I'd never be the same." (Ellison, 1995, p.225) At that time, the man will become numb and feel he is not the same as before. Invisible man was looking for a job hopefully with confidence in Dr. Bledsoe. One day he found his hope and expectation had collapsed and was been cheated all the time, all the wounds he suffered came upon him. Of course, he felt helpless and numb, which inferred the symptom of constriction.

\section{B. As a Worker at the Liberty Paints Plant}

Invisible man got a job at the liberty paints plant, but he was transferred to work in the basement of the production of color carrier because he mistook the paint remover for an additive. One day he was fighting with the foreman who always found faults with him, and then no one check the pressure gauge, causing an explosion in the workshop. He found that he was lying in hospital as an experiment for doctors. Doctors and nurse are so cruel that they continued conducting their experiment regardless of his pain. All the damage made him feel numb and began to think about his identity. Having experienced so many traumas at the Liberty Paints Plant, he showed the following symptoms:

\section{Hyperarousal}

According to Herman, patients' bodies are always on the alert for danger, they also have an extreme startle response to unexpected stimuli, as well as an intense reaction to specific stimuli associated with the traumatic event. A traumatic person will be on high alert at all times, such as the protagonist did as a worker. (Herman, 2015)

During invisible man's working at the liberty paints plant, he was careful to deal with the foreman Kimbro. When Kimbro checked the paint he stirred, he felt something was different and suspected Kimbro was cheating him just as Dr. Bledsoe did. Trauma patients always are on high alert for fear that they will be hurt again. (Herman, 2015) Invisible man was so afraid of the white man Kimbro scolding or publishing him that he felt very nervous and timid when his work was checked. Invisible man's attitude towards Kimbro is a black man's fear when he confronted a white man.

\section{Intrusion}

According to Herman, reviving a traumatic experience, whether in the form of memories, dreams or actions, carries with the emotional intensity of the original event. The survivor is continually buffeted by terror and rage. (Herman, 2015)

After invisible man was transferred to work in basement, he accidently came in the workers' conversation. He was slighted and ignored by these workers as before, which made him feel angry. "The sudden change made me puzzled and angry, as though they were making me the butt of a joke." (Ellison, 1995, p.259) "Here in this room, my defenses were negated, stripped away and checked at the door as the weapons, the razors and pistols of the country boys checked on Saturday night at the Golden Day." (Ellison, 1995, p.261) Here, invisible4 man experienced the feeling of being ignored and humiliated by others again. He felt that he was hated by everyone here, which reminds him of the fact that he lived with hostility all his life. At that time, he felt angry but there was nothing he could do.

\section{Constriction}


When traumatic patient shows the symptom of constriction, he may feel no longer fear but actually reality is constantly being distorted though it seems that he returns to normal life. (Herman, 2015)

Invisible man was lying in hospital as an experiment after the workshop exploded. Doctors are conducting experiment regardless of his pain. He felt no fear after he was discharged from the hospital: "I was no longer afraid. Not of important men, not of trustees and such; for knowing now that there was nothing which I could expect from them, there was no reason to be afraid." (Ellison, 1995, p.295) At that time, he was no longer afraid of others. After experiencing so many traumas, invisible man turned into a zombie and suspected his identity. He alternated between sobriety and confusion: "We, he, him -- my mind and I -- were no longer getting around in the same circles." (Ellison, 1995, p.295) Traumatic events provide a powerful trigger for entering a trance state. At that time, invisible man has been traumatized by his trauma experience so that he became numb and absent-minded.

\section{As a Spokesman for the Brotherhood}

Invisible man was saved by a woman named Mary when he fainted in the street because of weakness. Subsequently, he witnessed an elderly black couple violently evicted from an apartment building by whites who reclaimed their rental home. Angered by the incident, he led the crowd in protest which made him be invited to join the brotherhood by Jack who appreciated his gift for public speaking. Invisible man worked hard for the brotherhood but actually he was taken advantage as a tool to preserve the organization at the expense of Harlem blacks. Due to what he experienced in the Brotherhood, there are following symptoms can be found in him.

\section{Hyperarousal}

When traumatic person shows the symptom of hyperarousal, he will keep alert on everyone lest they will hurt him like Dr. Bledsoe did before.

Later on, invisible man was chased by police on the account that his speech caused revolt. A kind white girl showed him the way to flee, however, he suspected her motivation and showed the symptom of hyperarousal at this time, which can be seen in his mental activity. For example, "Had she put the man on my trail? What was she doing there?" (Ellison, 1995, p.336) It can be seen that he was wary of anyone. And then, his speech talent attracted the organizer of the brotherhood to accost him. However, he was careful and nervous during their conversation due to so many traumas he experienced. And we can find the sign as following: "Suddenly would tight as a tension spring I turned almost lethargically." (Ellison, 1995, p.337) "I was tense again" (Ellison, 1995, p.339) "I said tensely, 'What are you trying to do?" (Ellison, 1995, p.341) These descriptions embodied invisible man's symptom of hyperarousal which refers to his hypertension.

\section{Intrusion}

When traumatic person shows the symptom of intrusion, the similar experience will remind him of his painful memory and feel guilty if not help people in pain.

On a cold New York Street, invisible man was seeing that an elderly couple was evicted by whites and noticed the photo of couple when they were young. Their eyes were staring at him, which made him felt that a kind of rummy memory was awaken and reverberated in his mind. He picked up an identity card from the ground, written "Liberty ID Card". Due to it, his hands were shaking and breathing fast. The scene aroused his feelings of deprivation, bringing back his painful memory. Trauma patients will experience his pain again when he in a similar situation. Thus, when invisible man was seeing that couple was experiencing pain he can regard them in empathetic light. When the trauma patient witnesses others' pain, he will produce strong feelings of guilt. Therefore, invisible man delivered a speech for the couple and organized the crowd in protest.

\section{Constriction}

When traumatic person shows the symptom of constriction, he is easy to be in trance states. After invisible man fled to underground, he was whirling on in the blackness. Finally, he could barely move, and lay beyond the point of exhaustion. As the author described in this novel: "It was a state neither of dreaming nor of waking, but somewhere in between, in which I was caught like Trueblood's jaybird that yellow jackets had paralyzed in every part but his eyes." (Ellison, 1995, p.663) After experiencing so many traumas, he has been in trance state. In his illusion, he smiled at Jack and no longer felt scared. As the author described: “And Jack came closer, threatening, and I laughed. 'I'm not afraid now' I said." (Ellison, 1995, p.665) A traumatic person in the state of constriction will feel numb and no longer afraid of anything.

\section{Fail in Recovering from Trauma}

\section{Fail to Establish Safety}

The first stage of recovering from trauma is to establish safety, but invisible man failed at it. Establishing safety begins by focusing on control of the body and gradually moves outward control of the environment (Herman, 2015) However, invisible man fails to rebuild a sense of trust, which attributes to the society full of racial discrimination.

In this novel, invisible man was taken to join the fight between black boys and then crawled the electric blanket. Even so, he was still filled with hope to the college, trying to get recognition. After he made a mistake, he chose to 
believe that Dr. Bledsoe would help him find a good job. However, the fact that it is just Dr. Bledsoe's conspiracy made him feel powerless and unsafe. Because of it, invisible man became more careful when he dealt with others. Nevertheless, in order to prove his identity, he still trusted Jack and joined his organization to devote himself. Again, his trust was not rewarded in the brotherhood. It is their deception that hinders his efforts to establish safety. He believed again and again only to be cheated again and again. The safety he had just established was shattered again and again, which doomed him to failure. "Because no one can establish a safe environment alone, the task of developing an adequate safety plan always includes of a component of social support." (Herman, 2015, p.160) There's no social support but only deception and hurt in the white dominated society, which implied that his failure to establish safety.

\section{Fail to Tell Traumatic Experience}

Telling traumatic experience can contribute to the recovery of trauma, which is the second stage of recovering from trauma. However, the protagonist also failed at it. When traumatized person feel powerless and despaired, it is necessary for him to find support from someone trustworthy by sharing his sad experience.

In this novel, almost all the people were hostile to him or pretended to giving him a hand. There's nobody trustworthy for him to pour out his sad story. Even though there's someone to be trusted, he didn't choose to tell his traumatic experience. After he was been experimented by the doctor in factory hospital, he was saved by a kind woman Mary. Mary offered him accommodation and encouraged him to trust himself, gradually invisible man started to trust Mary. But even so, he never told them his suffering. For an invisible man, it is essential for them to find someone trustworthy to rely on. Unfortunately, invisible man failed to tell his sad stories from beginning to end.

\section{Fail to Reconnect with Others}

The third stage of recovering from trauma is to reconnect with others, which wasn't finished by invisible man. Traumatized person has to develop a new self and relationship if he or she tries to recover from traumatic experience. Herman put it that, "if the survivor is lucky enough to have supportive family, lovers, or friends, their care and protection can have a strong healing influence." (Ellison, 2015, p.63) It can be seen that no one can recover from the traumatic experience alone and they have to heal his psychological trauma relay on the new relationship with others.

As we can see in this novel, there's no trustworthy man for invisible man to depend on. For Dr. Bledsoe, an excellent black man, encouraged invisible man to work hard for his life as his idol. But what he actually did for invisible man's mistake betrayed his trust. Thus, the new relationship between invisible man and Bledsoe fails to establish. In brotherhood, he was invited to make speech by Jack for the organization. He worked hard for the organization so that he could get recognition from others. At last, he found that the purpose of this organization is not to work for citizen but to preserve the organization at the expense of the black's interests. Thus, the relationship between them is broken. As Herman put it that traumatic events shatter the sense of connection between individual and community, creating a crisis of faith. (Herman, 2015) Almost these people around invisible man are not honest to him, the loss of faith of the society made the impossibility of reconnecting with others.

\section{The INFLuence of Traumatic ExPERIENCE ON INVISIBLE MAN’s SELF-SEARCHING}

\section{A. Psychological Changes}

During his self-searching, invisible man suffered a lot from traumatic experience, which has an impact on his psyche. Thus, it is necessary for us to pay attention to the protagonist's psychological changes.

As a college student, he was innocent to plan for his future until when he was experimented in hospital, therefore he started to suspect his identity. As a spokesman in brotherhood, he was cheated and his dream was broken, which made him realize his real identity- an invisible man. Thus, his psychological changes can be divided into three stages: innocence, suspicion and realization.

Invisible man lived in the south of America and looked forward to achieve his naive dream. Because of his excellent performance in the graduation ceremony, he was invited to make a speech at white social gathering, which made him proud. Invisible man considered it as an honorable affair and prepared for it carefully. Unexpectedly, it is actually a kind of battle royal for the white to entertain themselves. In order to deliver his speech, he did what the white required according to grandfather's last words. Finally, he was rewarded for a briefcase which stands for the responsibility and duty. But the naive boy didn't get it that the white just wanted him to perform the duties of a slave. He was educated to please the white to get their recognition when he was a child. Thus, he tried to finish something that make the white satisfied after he entered the college due to scholarship. During his conversation with Mr. Norton, the board director repeated that you were my fate, which was not understood by the pure black man. He just felt that Dr. Norton was a kind man from surface, while actually there's deep racial discrimination in his mind. What is discussed above shows that invisible man is a pure, innocent and ignorant man who just hope to achieve his American dream by his hard work.

At the beginning, invisible man is always filled with hope for his dream and future. Even having so much traumatic experience, he still hoped to find his own identity. However, the cruel reality made him suspect his real identity in the society and the belief he followed. Gradually he realized that his identity actually is an invisible man. The first weakening is that he found Dr. Bledsoe's deception when he longed to get a good job with the faith in Bledsoe. It is ironically that Bledsoe, his idol, trick him all the time and break his dream. The second weakening is that he found he 
was lying in hospital to be experimented by cruel doctors. He found a job in New York and work hard for his future. However, the whites' hypocrisy made him suspect his grandfather's counsel "Do as the white do". He started to suspect the belief he followed is whether right or not. After workshop explosion, lying in hospital, he asked himself: "WHAT IS YOUR NAME?" (Ellison, 1995, p.281) That is to say, he started to suspect his identity. At that time, he became angry and suspicious rather than pure and innocent. The third realization is that when he was saved by a black woman Mary and looked after by her. Mary encouraged him to achieve his dream and accept the black culture. Invisible man realized that he should try to accept black culture and no need to be shameful as a black man. Afterwards, he was invited to join the organization Brotherhood, unfortunately, he found that the white in this organization considered the black as political tools to help them preserve the organization as political tools. That is the fourth realization for invisible man. In the white dominated society, black men are forced to obey the white at the expense of sacrificing themselves. Finally, he realized that the reason why his identity is an invisible man is that the white didn't want to recognize their existence. "All his frustrations were rooted in his skin, which made accept the darkness of darkness in the end." (Wang, 1999, p.126)

\section{B. Identity Realization}

In this story, the protagonist was searching for himself all the time, and the process of searching can be divided into three parts:

Firstly, he was so innocent without shame of his skin and work hard to achieve his dream. "He loses himself totally, firmly believing that being obedient and servile, he will be helped by the white to achieve his American dream." (Wang, $\mathrm{Xu}, 2014$, p.88) Thus, as for the invitation to make a speech from the white, he regarded it as an honor. Even the prize briefcase which infers that he should be on the blacks' duty was seen as an award by him. Thus, he was pleased to enter the college and filled with hope of his future without suspecting his identity. Secondly, after being cheated by Dr. Bledsoe, he felt a lot of despair but still wanted to achieve his dream when he worked at the Liberty Paints Plant. However, after an explosion, he was experimented in hospital by doctors who ignored his feelings. At that time, the protagonist began to suspect his real identity. There are several questions lingered in his mind: "Who are you?" "What's your mother's name?" "Who is your mother?" Actually, "the protagonist's experience at the Liberty Paint Plant and its hospital is a turning point in his quest for self-identity." (Wang, Xu, 2014, p.90) Thirdly, he was suffered from the organization Brotherhood as being cheated by Dr. Bledsoe. Experienced so much trauma in the course of his searching, he realized his non-identity. Finally, he realized his invisibility and accepted the reality that he was not recognized with responsible identity.

\section{CONCLUSION}

As one of the most influential black writers, Ralph Ellison vividly depicted the black's life in the society full of racial discrimination. His wonderful work Invisible Man describes that a young black man is seeking for his identity in the white dominated society. Besides an introduction of the author and work, this paper focuses on the protagonist's traumatic experience, symptoms and recovery.

In this novel, the protagonist experienced a lot of traumas in the process of self-identity. As a college student, he tried his best to finish the task Dr. Bledsoe assigned but surprisingly was cheated by the president later. As a worker at the Liberty Paints Plant, experienced an explosion, he found that he was experimented by cruel doctors. As a spokesman in Brotherhood, he devoted himself in the organization to achieve his dream but to found that he was just a tool to help the white preserve the organization. In such society, no one can give the protagonist help to recover from his trauma experience. Invisible man presented three symptoms: hyperarousal, intrusion, constriction. In his recovery, he failed at establish safety, tell traumatic experience and reconnect with others. Finally, he realized his real identity and chose to live underground.

This paper offered readers a different perspective of the study of Invisible Man with the help of Trauma and Recovery written by Herman. Through the analysis of the protagonist's trauma, it can help readers have a better understanding of this essay.

\section{REFERENCES}

[1] Caruth, Cathy. (2016). Unclaimed Experience: Trauma, Narrative and History. Baltimore: Johns Hopkins University Press.

[2] Ellison, Ralph. (1995). Invisible Man. New York: Vintage International.

[3] Herman, Judith. (2015). Trauma and Recovery. New York: Basic Books.

[4] Tao Jiajun. (2011). The Key Word of Western Thesis--Trauma. Foreign Literature (4): 117-125

[5] Wang Fengzhen. (1999). Invisible Man Is Still Shocking. Foreign Literature Studies (3):125-128

[6] Wang Lili. (1993). Ralph Ellison, American Writer and The Invisible Man. Foreign Literature (16): 78-83

[7] Wang Xiaowei, Xu Ling. (2014). As Study of the Theme of Initiation of Ralph Ellison's Invisible Man. Comparative Literature: East \& West 1:87-95.

[8] Xu Jun. (2018). Interpretation from the Perspective of the Wound Theory "Kill me, heal me". Anhui Literature.424 (11): 187-190 
Xinyao Du was born in Chongqing, China, in 1997. She received her bachelor of arts degree in Chongqing Normal University in 2019. She is currently a graduate student majoring in English education in Chongqing Normal University. And she is interested in English literature and teaching research. 